\title{
AVALIAÇÃO DA CAPACIDADE DE REGENERAÇÃO IN VITRO EM TOMATEIRO INDUSTRIAL'
}

\author{
MIKLÓS FÁRI ${ }^{2}$, GERALDO MILANEZ DE RESENDE ${ }^{3}$ e NATONIEL FRANKLIN DE MELO ${ }^{4}$
}

\begin{abstract}
RESUMO - Este trabalho teve por objetivo avaliar a capacidade de regeneração das cultivares de tomateiro industrial (Lycopersicon esculentum Mill) IPA-5 e IPA-6, utilizando quatro composições de meio de cultura descritos na literatura e cinco variações de inoculação. Foi testada uma nova variação de inoculação, denominada cotilédone fendido. A maior freqüência de formação de gemas vegetativas foi $100 \%$ no caso de IPA-5, e 65\% no caso de IPA-6. Para induzir o alongamento de brotos, foram necessários três subcultivos dos explantes apresentando gemas. No caso de IPA-5, o número de brotos obtidos foi maior quando a indução de gemas foi realizada em meio contendo BAP $\left(2,5 \mathrm{mg} \mathrm{L}^{-1}\right)$ e AIA $\left(0,2 \mathrm{mg} \mathrm{L}^{-1}\right)$ seguido de três subcultivos, em meio como zeatina $\left(0,5 \mathrm{mg} \mathrm{L}^{-1}\right)$. Usando esse protocolo, a cultivar IPA-5 produziu uma média de 5,45 brotos alongados a partir do cotilédone fendido. Essa capacidade excedeu significativamente o cotilédone aparado, que produziu 4,4 brotos alongados por explante. No caso de IPA-6, a melhor combinação de meios e método de inoculação produziu 0,87 broto alongado por explante. Os brotos alongados foram enraizados e transferidos para casa de vegetação.

Termos para indexação: Lycopersicon esculentum, cultivares, organogênese, cultura de tecidos, cotilédone, explante, transformação genética.
\end{abstract}

EVALUATION OF THE IN VITRO REGENERATION CAPACITY IN BRAZILIAN INDUSTRIAL TOMATO

\begin{abstract}
The objective of this work was to evaluate the regeneration capacity of the IPA-5 and IPA-6 Brazilian industrial tomato (Lycopersicon esculentum Mill) cultivars using four compositions of culture media described in the literature and five inoculation methods. A new variation of inoculation, the split cotyledon method, was also tested. The largest frequency of shoot bud formation was $100 \%$ in the case of IPA-5 and $65 \%$ in the case of IPA-6. To induce shoot elongation, it was necessary to accomplish three subcultures of the explants presenting shoot buds. In the case of IPA-5, the number of the obtained shoots was higher when the induction of shoot buds was accomplished in culture medium containing BAP $\left(2.5 \mathrm{mg} \mathrm{L}^{-1}\right)$ and IAA $\left(0.2 \mathrm{mg} \mathrm{L}^{-1}\right)$ followed by three subcultures on zeatin $\left(0.5 \mathrm{mg} \mathrm{L}^{-1}\right)$ containing medium. Using such protocol, the IPA-5 cultivar produced, on the average, 5.45 elongated shoots through the split cotyledon method. That capacity exceeded significantly the trimmed cotyledon method, which produced 4.4 elongated shoots per explant. In the case of IPA- 6 , the best combination of culture medium and inoculation method produced 0.87 elongated shoot per explant. The elongated shoots were rooted and transferred to greenhouse.
\end{abstract}

Index terms: Lycopersicon esculentum, cultivars, organogenesis, tissue culture, cotyledons, explants, genetic transformation.

\footnotetext{
${ }^{1}$ Aceito para publicação em 11 de janeiro de 2000.

Trabalho realizado com recursos do convênio Embrapa/ CODEVASF/AGROINVEST (Hungria) e Agricultural Biotechnology Center, Gödölló, Szent-Györgyi A. út. 4., H-2100, Hungria.

${ }^{2}$ Eng. Agrôn., Ph.D., Embrapa-Centro de Pesquisa Agropecuária do Trópico Semi-Árido (CPATSA), Caixa Postal 23, CEP 56300-970 Petrolina, PE. E-mail: miklos@cpatsa.embrapa.br

${ }^{3}$ Eng. Agrôn., M.Sc., Embrapa-CPATSA.

E-mail: gmilanez@cpatsa.embrapa.br

${ }^{4}$ Biól., M.Sc., Embrapa-CPATSA.

E-mail: natoniel@npd.ufpe.br
}

\section{INTRODUÇÃO}

No Nordeste do Brasil, o cultivo do tomateiro apresenta-se como uma atividade agrícola de expressiva relevância sócio-econômica. Nos estados de Pernambuco e Bahia, maiores produtores de tomate industrial do Nordeste, a produtividade média obtida nos perímetros irrigados é considerada baixa $\left(40 \mathrm{t} \mathrm{ha}^{-1}\right)$, tendo em vista o grande potencial existente para a tomaticultura na região (Embrapa, 1994). Essa baixa produtividade está associada a sérios pro- 
blemas fitossanitários, sobretudo viroses, além do ataque de fungos e insetos-praga que criam a necessidade de se pesquisar novas alternativas ou obterse novos genótipos com resistência múltipla a doenças e pragas; entre esses, os estudos sobre a regeneração e transformação genética. No Brasil, a maior parte das áreas cultivadas com tomate para processamento vem sendo plantada com a cultivar IPA-5 (Giordano et al., 1997).

Para aumentar a produtividade, melhorar a qualidade, obtendo resistência contra estresses bióticos e abióticos, a engenharia genética abriu uma nova perspectiva para o melhoramento genético do tomateiro, a partir do final da década 80 (Wijbrandi \& Both, 1993). A cultura de tecidos tem um papel de destaque durante o processo da realização das técnicas de transformação genética, uma vez que é necessário induzir gemas vegetativas e, em seguida, regenerar brotos alongados e plantas completas a partir de células ou tecidos geneticamente modificados (McCormick, 1991).

Em geral, o tomate representa um bom exemplo para utilização das técnicas de regeneração in vitro. Nessa espécie, a regeneração de plantas foi estabelecida há aproximadamente 20 anos (Kut et al., 1984; Sink \& Reynolds, 1986), e métodos de regeneração têm sido relatados por diversos autores (Tan, 1987; McCormick, 1991; Redenbaugh et al., 1992; Wijbrandi \& Both, 1993; Asakura et al., 1995; Fári et al., 1995a; Rhim et al., 1995). A partir de 1995, foram publicados diversos métodos sobre transformação genética via Agrobacterium tumefaciens e Agrobacterium rhizogenes (Shahin et al., 1986; Sukhapinda et al., 1987), bem como sobre transformação genética direta de protoplastos (Koornneef et al., 1986; Jongsma et al., 1987; Pieterse \& Koornneef, 1988; Bellini et al., 1989). O tomateiro é uma das primeiras espécies, cujas cultivares transgênicas já foram comercializadas, principalmente no mercado americano (Redenbaugh et al., 1992).

No Brasil há poucos trabalhos na área de regeneração in vitro e de transformação genética de cultivares de tomateiro, e pouco se conhece sobre a capacidade de regeneração das principais cultivares brasileiras.

O objetivo deste trabalho foi avaliar o potencial da regeneração in vitro das cultivares IPA-5 e IPA-6, a partir de vários tipos de explantes e meios de cultura, gerando protocolos para sua regeneração in vitro que venham a subsidiar os métodos de transformação genética.

\section{MATERIAL E MÉTODOS}

Sementes comerciais das cultivares IPA-5 e IPA-6 foram desinfestadas em álcool etílico a $96 \%$, por um minuto, e em hipoclorito de sódio comercial a 20\% (v/v) com duas gotas de detergente comercial, durante 20 e 25 minutos, respectivamente. As sementes foram enxaguadas cinco vezes em água bidestilada esterilizada, e inoculadas em meio MS (Murashige \& Skoog, 1962) solidificado com $7 \mathrm{~g} \mathrm{~L}^{-1}$ de ágar-ágar sem reguladores de crescimento. O meio foi distribuído em caixas de plástico estéreis de cultura de tecidos Veg-Box (Agroinvest Ltda., Budapeste, Hungria) com capacidade de $425 \mathrm{~mL}$ de volume total. Todas as culturas foram mantidas em sala de crescimento, com temperatura de $25 \pm 2^{\circ} \mathrm{C}$, fotoperíodo de 16 horas e luminosidade de 2,5 klux.

O método de inoculação A (decapitação de plântulas) foi realizado conforme o protocolo descrito por Fári et al. (1995a). A decapitação foi realizada sete a oito dias após a semeadura, diretamente abaixo do nó do cotilédone. Em cada recipiente Veg-Box foram cultivadas 15 plântulas. No método B (cotilédones fendidos), os cotilédones foram fendidos ao longo da nervura central, da extremidade até sua metade, sete a oito dias após a semeadura. Dez cotilédones fendidos foram inoculados em cada placa de Petri. O método C (cotilédones inteiros) foi realizado de acordo com McCormick (1991). Os explantes de cotilédones foram excisados na parte basal do pecíolo, diretamente ao lado do nó cotiledonal, com a parte abaxial em contato com o meio. Trinta cotilédones inteiros foram inoculados por placa de Petri. Em relação ao método D (cotilédones aparados), seguiu-se o protocolo de Redenbaugh et al. (1992), que consistiu em aparar os cotilédones nas extremidades distal e proximal (ápice e pecíolo), sendo inoculados com a face abaxial em contato com o meio. Dez cotilédones aparados foram inoculados em placa de Petri. Conforme o protocolo aplicado por Rhim et al. (1995), estabeleceu-se o método E (primeiras folhas cortadas), no qual os brotos foram enraizados e cultivados em meio MS (Murashige \& Skoog, 1962), sem reguladores de crescimento, durante oito a dez dias. As primeiras folhas foram isoladas e cortadas em pequenos pedaços de $1 \mathrm{~cm}^{2}$, portando partes das nervuras principal e laterais. Os explantes foram cultivados com a face abaxial em contato com o meio. Oito explantes foram inoculados por placa.

Para induzir regeneração de gemas, os explantes foram cultivados em placas de Petri $(10 \mathrm{~cm}$ de diâmetro). 
Os reguladores de crescimento foram esterilizados por filtração e adicionados aos meios de cultura autoclavados e as placas vedadas com Parafilm. Os seguintes meios de cultura foram utilizados: M0: macro e micronutrientes de Murashige \& Skoog (1962), vitaminas de B5 de Gamborg et al. (1968) suplementado com $30 \mathrm{~g} \mathrm{~L}^{-1}$ de sacarose e de $8 \mathrm{~g} \mathrm{~L}^{-1}$ de ágar-ágar, $\mathrm{pH}$ 5,8; M1: meio de cultura M0 suplementado com $1 \mathrm{mg} \mathrm{L}^{-1}$ de zeatina, e $30 \mathrm{~g} \mathrm{~L}^{-1}$ de glicose, conforme McCormick (1991); M2: as vitaminas do meio de cultura M0 foram substituídas por vitaminas de Nitsch \& Nitsch (1969), suplementado com $2 \mathrm{mg} \mathrm{L}^{-1}$ de zeatina e $20 \mathrm{~g} \mathrm{~L}^{-1}$ de sacarose, de acordo com Redenbaugh et al. (1992); M3: meio de cultura M0 suplementado com 2,5 mg L-1 de BAP e $0,2 \mathrm{mg} \mathrm{L}^{-1}$ de AIA, segundo Rhim et al. (1995).

Para a obtenção de brotos alongados, os explantes com gemas foram repicados três vezes para os meios de cultura listados abaixo, em intervalos que variaram entre quatro e seis semanas, de acordo com a intensidade do crescimento. Primeiro ciclo de repicagem - meio de cultura R1: meio M2 suplementado com $0,5 \mathrm{mg} \mathrm{L}^{-1}$ de zeatina; segundo ciclo de repicagem - meio de cultura R2: meio M1 suplementado com $0,5 \mathrm{mg} \mathrm{L}^{-1}$ de zeatina, e terceiro ciclo de repicagem meio de cultura R3: meio M0 suplementado com $0,8 \mathrm{mg} \mathrm{L}^{-1}$ de zeatina. O intervalo entre repicagens foi de 30 dias.

Para enraizamento e aclimatação das plantas regeneradas, os brotos de 0,5-1,5 cm de comprimento foram isolados e subcultivados em meio M4 (meio de cultura M0 suplementado com $0,5 \mathrm{mg} \mathrm{L}^{-1}$ de AIA), os quais foram distribuídos em Veg-Box. As plântulas enraizadas foram transferidas para substrato esterilizado e aclimatadas em casa de vegetação.

Para análise estatística, em cada tratamento foram usadas cinco placas de Petri, e as razões de indução de regeneração foram registradas 28 dias após a inoculação. Todos os tratamentos foram repetidos duas vezes. $\mathrm{O}$ experimento foi realizado com delineamento inteiramente casualizado, em esquema fatorial $(2 \times 4 \times 5)$ composto por duas cultivares, quatro variações de meios de cultura de indução de regeneração (M0, M1, M2 e M3) e cinco métodos de inoculação/regeneração (A, B, C, D e E). A variável analisada foi o número de brotações, a qual foi realizada pelo software SANEST (Zonta \& Machado, 1989).

\section{RESULTADOS E DISCUSSÃO}

\section{Indução de regeneração}

No método A observou-se que a indução de regeneração foi mais rápida. As gemas vegetativas e pequenas folhas desenvolveram-se num período de
10 a 12 dias após a decapitação das plântulas. Ao redor da superfície de corte do hipocótilo formaram-se pequenas gemas, as quais originaram folhas com comprimento entre 0,5 e $0,8 \mathrm{~mm}$. A freqüência de indução (Tabela 1) dessas formações foi de $75 \%$ e 92\% para as cultivares IPA-6 e IPA-5, respectivamente.

Utilizando-se o método B, verificou-se, inicialmente, o alongamento dos explantes. De cinco a sete dias, foi observado formação de meristemas vegetativos ao longo do corte (Fig. 1A). No caso da cultivar IPA-5, obteve-se $100 \%$ de indução de regeneração (Tabela 1) nos meios M2 e M3. Com a IPA-6, produziu-se $65 \%$ de freqüência de indução de regeneração (Tabela 1) no meio M3.

Nas duas cultivares analisadas, o método de cotilédones inteiros - C - foi o menos efetivo, e os explantes permaneceram sem crescimento. No total, foi obtido indução de regeneração de $25 \%$, no caso de IPA-5, utilizando-se o meio M1. Na cultivar IPA-6, nenhuma regeneração foi obtida (Tabela 1).

Observou-se uma indução de regeneração nas duas posições de corte (Fig. 1A) no método D. A maior porcentagem de indução de regeneração (100\%) foi observada no meio M3, com a cultivar IPA-5 (Tabela 1). No meio M2, a cultivar IPA-6 apresentou $65 \%$ de indução de regeneração.

A mais baixa capacidade de indução de regeneração (Tabela 1) foi obtida no método E, com apenas $22 \%$ de indução de regeneração, com a cultivar IPA-5, no meio M2, e $23 \%$ de indução de regeneração com IPA-6, no meio M3.

\section{Alongamento de brotos das gemas regeneradas}

Para se obter elevada freqüência de alongamento de brotos de gemas vegetativas, foram necessários três ciclos de repicagem após a indução. Nos meios de indução, os explantes formaram um pequeno calo na superfície do corte, enquanto os meristemas induzidos criaram pequenas gemas, sem alongamento. As gemas começaram a se alongar apenas no segundo ciclo, ficando completas no terceiro ciclo, quando os brotos foram isolados e enraizados. Os resultados evidenciaram uma capacidade de alongamento de brotos extremamente alta na cultivar IPA-5, e pouco eficiente, no caso da cultivar IPA-6. 
TABELA 1. Freqüência de indução de regeneração in vitro de tomateiro cultivares IPA-5 e IPA-6'.

\begin{tabular}{|c|c|c|c|c|c|c|}
\hline \multirow[t]{2}{*}{ Cultivar } & \multirow[t]{2}{*}{$\mathrm{Meio}^{2}$} & \multicolumn{5}{|c|}{ Método de inoculação ${ }^{3}$} \\
\hline & & A & $\mathrm{B}$ & $\mathrm{C}$ & $\mathrm{D}$ & $\mathrm{E}$ \\
\hline \multirow[t]{4}{*}{ IPA-5 } & M0 & 92 & - & - & - & - \\
\hline & M1 & -4 & 11 & 25 & - & 0 \\
\hline & M2 & - & 100 & - & 80 & 11 \\
\hline & M3 & - & 100 & - & 100 & 22 \\
\hline \multirow[t]{4}{*}{ IPA-6 } & MO & 75 & - & - & - & - \\
\hline & M1 & - & 21 & 0 & - & 0 \\
\hline & M2 & - & - & - & 65 & 0 \\
\hline & M3 & - & 65 & - & 41 & 23 \\
\hline
\end{tabular}

1 Porcentagem de indução de gemas vegetativas expressa com dados acumulados.

2 M0: Murashige \& Skoog (1962); M1: McCormick (1991); M2: Redenbaugh et al. (1992); M3: Rhim et al. (1995).

3 A: decapitação (SDM, após Fári et al., 1995a); B: cotilédone fendido; C: cotilédone inteiro (McCormick, 1991); D: cotilédone aparado (Redenbaugh et al., 1992); E: primeira folha cortada (Rhim et al., 1995).

4 Não foi estudado.
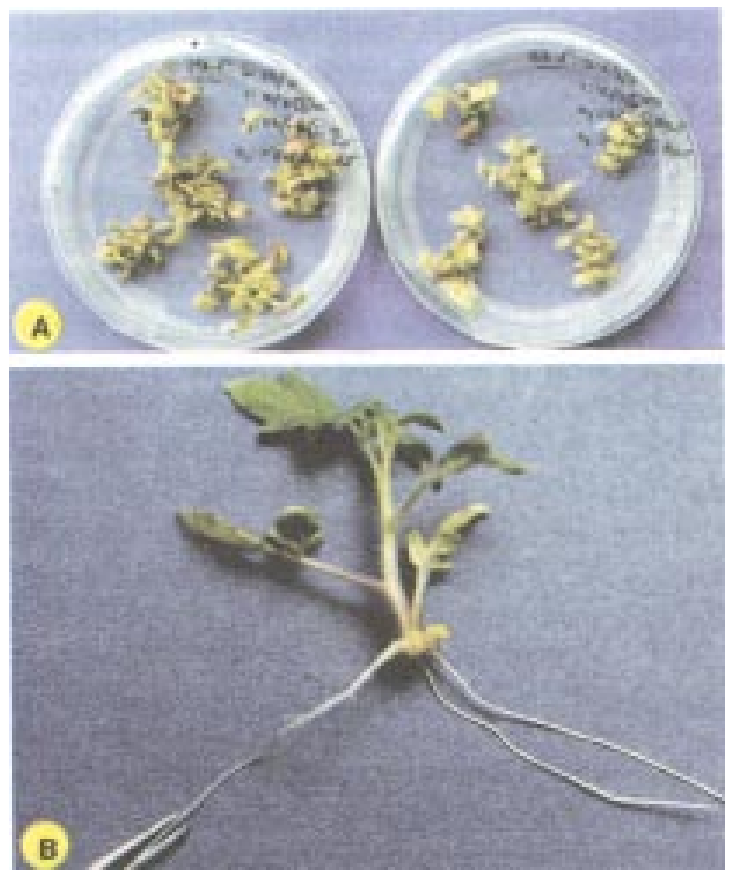

FIG. 1. Regeneração in vitro de tomateiro cultivar IPA-5. A: indução de regeneração a partir de cotilédone fendido (à esquerda) e a partir de cotilédone aparado (à direita); B: planta regenerada após o enraizamento.

Com relação ao alongamento de brotos após a indução de regeneração, com a aplicação de BAP e AIA e subcultivo dos explantes com adição de zeatina
(Tabela 2), observou-se que o número de brotos alongados aumentou do segundo para o terceiro ciclo, no caso das duas cultivares. Vinte explantes de cotilédones fendidos (método B) da cultivar IPA-5 produziram 77 brotos alongados, no terceiro ciclo de repicagem, e 32 brotos no ciclo anterior. Essa combinação foi a mais produtiva. Em média, 5,45 brotos alongados foram obtidos de cada explante (Tabela 2). A cultivar IPA-6 produziu também mais brotos alongados durante o terceiro ciclo.

Entre os métodos de inoculação, observou-se, na cultivar IPA-5, que os cotilédones fendidos produziram significativamente mais brotos (em média 5,45 brotos) do que os cotilédones aparados, com média de 4,44 brotos. Nas mesmas combinações, a cultivar IPA-6 produziu significativamente menor número de brotos alongados $(0,87$ e 0,86 , respectivamente).

Os dados referentes ao alongamento de brotos, após a indução de regeneração com a aplicação de zeatina e subcultivo dos explantes com adição de zeatina, são apresentados na Tabela 2 .

Na cultivar IPA-5, foram obtidos menos brotos alongados, dependendo do método de inoculação. Essa tendência foi primeiramente observada no terceiro ciclo de repicagem, quando a quantidade de brotos alongados decresceu. A mesma tendência foi observada na cultivar IPA-6.

Dos explantes de primeiras folhas cortadas (método $\mathrm{E}$ ), produziu-se apenas um pequeno núme- 
TABELA 2. Capacidade de alongamento de brotos de tomateiro cultivares IPA-5 e IPA-6 cultivados in vitro durante o segundo (R2) e terceiro ciclo (R3) de repicagem.

\begin{tabular}{|c|c|c|c|c|c|c|c|}
\hline \multirow[t]{2}{*}{ Cultivar } & \multirow[t]{2}{*}{ Meio } & \multirow[t]{2}{*}{ Método } & \multirow{2}{*}{$\begin{array}{c}\mathrm{N}^{\mathrm{o}} \mathrm{de} \\
\text { explantes }\end{array}$} & \multicolumn{2}{|c|}{ № de gemas/broto alongado } & \multirow{2}{*}{$\begin{array}{c}\text { № total de brotos } \\
\text { alongados }\end{array}$} & \multirow{2}{*}{$\begin{array}{c}\text { № médio de brotos } \\
\text { alongados }\end{array}$} \\
\hline & & & & $\mathrm{R} 2$ & R3 & & \\
\hline \multirow[t]{5}{*}{ IPA-5 } & $\mathrm{BAP}+\mathrm{AIA} /$ zeatina & Método B & 20 & 32 & 77 & $109 a$ & 5,45 \\
\hline & & Método D & 18 & 20 & 60 & $80 b$ & 4,44 \\
\hline & Zeatina/zeatina & Método B & 8 & 10 & 9 & $19 \mathrm{e}$ & 2,37 \\
\hline & & Método D & 25 & 13 & 2 & $15 f$ & 0,60 \\
\hline & & Método E & 36 & 3 & 0 & $3 h$ & 0,08 \\
\hline \multirow[t]{4}{*}{ IPA-6 } & BAP+AIA/zeatina & Método B & 29 & 10 & 15 & $25 \mathrm{~d}$ & 0,86 \\
\hline & & Método D & 31 & 5 & 22 & $27 \mathrm{c}$ & 0,87 \\
\hline & Zeatina/zeatina & Método D & 20 & 14 & 3 & $17 f$ & 0,85 \\
\hline & & Método E & 30 & 5 & 6 & $11 \mathrm{~g}$ & 0,35 \\
\hline
\end{tabular}

${ }^{1}$ Médias seguidas da mesma letra não diferem entre si, pelo teste de Tukey a $1 \%$ de probabilidade.

ro de brotos alongados (IPA- $5=0,08$ broto/explante e IPA- $6=0,35$ broto/explante).

\section{Enraizamento e aclimatação das plantas regenera- das}

Com quatro a cinco dias após a repicagem, os brotos apresentaram sistema radicular desenvolvido (Fig. 1B). Após 18 e 21 dias, foram transferidos para substrato e aclimatados.

A análise da cultivar IPA-5 demonstra que os métodos cotilédone fendido e cotilédone aparado produzem $100 \%$ de indução de regeneração. Nessa cultivar foi observado que apenas os explantes cultivados em meio de indução contendo BAP e AIA produziram alta freqüência de alongamento durante os ciclos de repicagem. Quando o meio de indução foi suplementado apenas com zeatina, o número de brotos alongados obtidos durante os ciclos de subcultivo foi consideravelmente menor. Resultados semelhantes foram descritos por McCormick (1991), utilizando a cultivar VF36.

Na cultivar IPA-5, foi observado que o cotilédone fendido possui uma capacidade de regeneração de brotos alongados $20 \%$ maior do que o método cotilédone aparado utilizado por Redenbaugh et al. (1992). Supõe-se que a maior superfície de corte tenha influência significativa sobre esse fenômeno. Fári et al. (1995b), trabalhando com transformação genética de berinjela (Solanum melongena), obser- varam que a maior superfície de corte do cotilédone resulta em maior capacidade de regeneração e consideravelmente maior frequiência de transformação genética.

De acordo com os resultados obtidos, a regeneração das cultivares IPA-5 e IPA-6 pode ser realizada em quatro ciclos de cultivo; sendo um ciclo para a indução de regeneração e três para obtenção de alongamento de brotos.

\section{CONCLUSÕES}

1. As cultivares de tomate IPA-5 e IPA-6 possuem alto potencial de organogênese espontânea, confirmado pelo método de decapitação.

2. Para regeneração das cultivares IPA-5 e IPA-6 são necessários um ciclo de cultivo para a indução de regeneração e três ciclos para a obtenção de alongamento de brotos.

3. A cultivar IPA-5 é ideal para os estudos de regeneração in vitro e para a engenharia genética; produz média de 5,45 brotos alongados a partir do cotilédone fendido e 4,44 brotos alongados por explante em cotilédone aparado; o número máximo de brotos é obtido quando a indução de gemas é realizada em meio com BAP $\left(2,5 \mathrm{mg} \mathrm{L}^{-1}\right)$ e AIA $\left(0,2 \mathrm{mg} \mathrm{L}^{-1}\right)$, e, depois, durante três ciclos de subcultivos, quando é aplicado apenas zeatina $\left(0,5 \mathrm{mg} \mathrm{L}^{-1}\right)$. 


\section{AGRADECIMENTOS}

À Embrapa-Centro de Pesquisa Agropecuária do Trópico Semi-Árido; à Companhia de Desenvolvimento do Vale do São Francisco e à AGROINVEST, Budapeste, Hungria, pelo financiamento deste projeto, via colaboração internacional com o Agricultural Biotechnology Center, Gödölló, Hungria.

\section{REFERÊNCIAS}

ASAKURA, N.; MISOO, S.; KAMIJIMA, O.; SAWANO, M. High frequency regeneration of diploid from apical end of cultured hypocotyl tissue in tomato. Breeding Science, Tokyo, v. 45, n.3, p.455-459, 1995.

BELLINI, C.; CHUPEAU, M.C.; GUERCHE, P.; VASTRA, G.; CHUPEAU, Y. Transformation of Lycopersicon peruvianum and Lycopersicon esculentum L. mesophyll protoplasts by electroporation. Plant Science, Limerick, v.65, n.1, p.63-75, 1989.

EMBRAPA. Centro de Pesquisa Agropecuária do Trópico Semi-Árido (Petrolina, PE). Recomendações técnicas para o cultivo do tomate industrial em condições irrigadas. Petrolina : Embrapa-CPATSA/ FUNDESTONE, 1994. 52p. (Embrapa-CPATSA. Circular Técnica, 30).

FÁRI, M.; CSÁNYI, M.; MITYKÓ, J.; SZÁSZ, A.; CSILLAG, A. An alternative pathway of in vitro organogenesis in higher plants: plant regeneration via decapitated hypocotyls in three solanaceous vegetable genera. Kertészeti Tudomány, Budapest, v.27, n.1/2, p.9-15, 1995a.

FÁRI, M.; NAGY, I.; CSÁNYI, M.; MITYKÓ, J.; ANDRÁSFALVY, A. Agrobacterium mediated genetic transformation and plant regeneration via organogenesis and somatic embryogenesis from cotyledon leaves in eggplant (Solanum melongena cv. Kecskeméti lila). Plant Cell Reports, Berlin, v.15, n.1, p.82-86, 1995 b.

GAMBORG, O.L.; MILLER, R.A.; OJIMA, K. Nutrient requirements of suspension cultures of soybean root cells. Experimental Cell Research, San Diego, v.50, n.1, p.151-158, 1968.

GIORDANO, L. de B.; BOITEUX, L. da S.; SANTOS, J.R.M. dos; CHARCHAR, J.M.; LOPES, C.A.
Tx 401-08: linhagem de tomate para processamento industrial, com resistência múltipla a doenças. Horticultura Brasileira, Brasília, v.15, n.2, p.123126, nov. 1997.

JONGSMA, M.; KOORNNEEF, M.; ZABEL, P.; HILLE, J. Tomato protoplast DNA transformation: physical linkage and recombination of exogenous DNA sequences. Plant Molecular Biology, Dordrecht, v.8, n.3, p.383-394, 1987.

KOORNNEEF, M.; HANHART, C.; JONGSMA, M.; TOMA, I.; WEIDE, R.; ZABEL, P.; HILLE, J. Breeding of tomato genotype readily accessible to genetic manipulation. Plant Science, Limerick, v.45, n.2, p.201-208, 1986.

KUT, S.A.; BRAVO, J.E.; EVANS, D.A. Tomato. In: AMMIRATO, P.V.; EVANS, D.; SHARP, W.R.; YAMADA, Y. (Ed.). Handbook of plant cell culture. New York : MacMillan, 1984. v.3, p.247289.

McCORMICK, S. Plant tissue culture manual: transformation of tomato with Agrobacterium tumefaciens. New York: Kluwer, 1991. p.1-9.

MURASHIGE, T.; SKOOG, F.A. Revised medium for rapid growth and bioessays with tobacco tissue culture. Physiologia Plantarum, Copenhagen, v.15, n.5, p.473-497, 1962.

NITSCH, J.P.; NITSCH, C. Haploid plants from pollen grains. Science, Washington, v.163, n.3863, p.8587, 1969.

PIETERSE, C.; KOORNNEEF, M. Optimization of direct gene transfer in tomato. In: PUITE, K.J.; DONS, J.J.M.; HUNZING, H.J.; KOOL, A.J.; KOORNEEF, M.; KERNS, F.A. (Ed.). Progress in plant protoplast research. Dordrecht : Kluwer, 1988. p.357-358.

REDENBAUGH, K.; HIATT, W.; MARTINEAU, B.; KRAMER, M.; SHEEHY, R.; SANDERS, R.; HOUCK, C.; EMLAY, D. Safety assessment of genetically engineered fruits and vegetables: a case study of the Flavr Savr ${ }^{\mathrm{TM}}$ tomato. London : CRC, 1992. 267p.

RHIM, S.L.; CHO, H.J.; KIM, B.D.; SCHNETTER, W.; GEIDER, K. Development of insect resistance in tomato plant expressing the delta-endotoxin gene of Bacillus thuringiensis subsp. tenebrionis, Molecular Breeding, Dordrecht, v.1, n.2, p.229-236, 1995. 
SHAHIN, E.A.; SUKHAPINDA, K.; SIMPSON, R.B.; SPIVEY, R. Transformation of cultivated tomato by a binary vector in Agrobacterium rhizogenes: transgenic plants with normal phenotypes harbor binary vector T-DNA, but no Ri-plasmid T-DNA. Theoretical and Applied Genetics, Berlin, v.72, p.770-777, 1986.

SINK, K.C.; REYNOLDS, J.F. Tomato (Lycopersicon esculentum L.). In: BAJAJ, Y.P.S. (Ed.). Biotechnology in agriculture and forestry: crops I. Berlin : Springer, 1986. v.2, p.319-344.

SUKHAPINDA, K.; SPIVEY, R.; SIMPSON, R.B.; SHAHIN, E.A. Transgenic tomato (Lycopersicon esculentum L.) transformed with a binary vector in
Agrobacterium rhizogenes: non-chimeric origin of callus clone and low copy numbers of integrated vector T-DNA. Molecular and General Genetics, Berlin, v.206, p.491-497, 1987.

TAN, M.M.C. Somatic hybridization and hybridization in some solanaceae. Amsterdam : Free University of Amsterdam, 1987. 111p. Ph.D. Thesis.

WIJBRANDI, J.; BOTH, M.T.J. de. Temperate vegetable crops. Scientia Horticulturae, Amsterdam, v.55, n.1, p.37-63, 1993.

ZONTA, E.P.; MACHADO, A.A. SANEST: sistema de análise estatística. Porto Alegre : UFRGS-Departamento de Estatística, 1989. Software. 